\title{
Mindfulness and Critical Thinking: Why Should Mindfulness Be the Foundation of the Educational Process?
}

\author{
Eva Škobalj \\ Prva gimnazija Maribor (First Gymnasium of Maribor), Slovenia
}

Copyright $\bigcirc 2018$ by authors, all rights reserved. Authors agree that this article remains permanently open access under the terms of the Creative Commons Attribution License 4.0 International License

\begin{abstract}
Teaching critical thinking to pupils and students stands as one of the most crucial goals of education. The existing professional literature offers a wide range of definitions for critical thinking along with a variety of perspectives on the topic. The same can also be said of the approaches that a teacher should use to encourage pupils to think critically. Such a variety is undoubtedly desired as it opens up new questions and breeds the necessity for further inquiry. At the same time, it is vital that we constantly build upon and deepen the concept of critical thinking in accordance with modern day requirements and general development. Regardless of the universal consensus on what critical thinking is and how to approach it, it is necessary, at least to some extent, to develop a relatively conceptual consistency among teachers though it seems neither possible nor logical. This article deals with establishing the connection between critical thinking and mindfulness, which is presented as the foundation or condition upon which it is possible to develop critical thinking abilities. Numerous definitions of mindfulness from professional literature have been included for this very purpose as well as the many parallels between mindfulness and critical thinking. The article describes mindfulness, not as a new concept only appearing in the present day, but as a strategy reaching deep into the past all the way to, among others, ancient Greece. In the final phase of the article, mindfulness is outlined as a strategy that offers the power to build upon the critical thinking that we are familiar with today while also providing additional contemporary content.
\end{abstract}

Keywords Mindfulness, Responsibility, Critical Thinking

\section{Introduction}

Over the last few decades, the practice of mindfulness has spread throughout the world. It is this great interest in mindfulness that illustrates particular deficits in (consumerist) society, which places comfort, pleasure, earnings and success being high on one's list of priorities. This tends to lead to a search for instant solutions, personal benefit, negligence, and, last but not least, an absence of ethical instincts. Mindfulness thus wins recognition as one of many possible ways we could put out this fire. The fact that it has taken big steps into numerous fields such as psychotherapy, positive psychology and psychological counselling as well as being ever more present in educational processes should not be surprising. It is the latter, the importance of mindfulness to the field of education, that is the subject of this paper.

In schools and educational institutions in recent years, there has been a sharp increase in the introduction of mindfulness practices into the educational process. Even in schools, we face a deficit, which is most often reflected in the low level of motivation of students, their lack of understanding of responsibility, low concentration skills and also in the sense of educational problems. The education and training of young people is undoubtedly a particularly sensitive area, which requires additional care. Therefore, it is understandable that questions arise, as well as some (initial) dilemmas as to what mindfulness actually is and how to apply it in practice. Is mindfulness really a new practice that discusses the all known methods or is it an upgrade of these methods, their in-depth understanding and application? Critical thinking is, for example, an already established practice and although there is no uniform consensus in this field and the "professional literature does not give a uniform answer as to what critical thinking is", [1] it is still firmly anchored in educational processes and represents one of their main goals and competences. This paper focuses on finding links between mindfulness and critical thinking. Can the understanding of the meaning and practice of mindfulness lead to both a better understanding of the critical thinking and acting in 
accordance with it? Can we add a new dimension to critical thinking through the practice of mindfulness? To what extent are the methods of mindfulness and critical thinking compatible?

The purpose of highlighting the above questions is the need for insight into the intellectual origin of mindfulness and critical thinking. This path takes us to ancient Greece, where the Socratic method of questioning presented a way in which an individual reorganized their views and beliefs when asked about the meaning of both acting and thinking (both his and that of others). In short, instead of an automatic response, conscious vigilance and logic based reasoning were invoked. All of these are, in the most general sense, the goals of critical thinking. To the same extent, the same goals could also be used to describe mindfulness. This paper concludes that the boundaries between mindfulness and critical thinking are difficult to determine or, in other words, that both practices intertwine and complement each other. Within a certain context, mindfulness is one of the conditions necessary for the development of critical thinking. Only those who observe events and phenomena can consciously see and observe them and raise further questions about them thus developing and upgrading their understanding of them.

The article further deals with the Socratic method of questioning as a point of contact between the two practices. Such questions exist as a driving force for development and progress. A modern teacher should be a Socratic teacher who appreciates and promotes the culture of (self) questioning. Critical thinking in schools is still (too) often only related to external events and the judgment of other people. The practice of mindfulness is complementary to critical thinking, thus, an individual can consider their own thoughts and, consequently, actions. This, of course, is closely linked to the development of individual responsibility. Parallels can also be found in the objectives of both practices. The goal of mindfulness is far more far-reaching than simply learning to cope with stress and attain a state of relaxation. The purpose of practicing mindfulness is not to search for pleasant feelings and to push away the unpleasant. The goal of both mindfulness and critical thinking is knowledge as well as an understanding of the causes and conditions of a particular phenomenon or the appearance of this phenomenon in a wider context. This leads to another step which is ethical cognition.

\section{Critical Thinking}

Although critical thinking is one of the fundamental competences in the educational process, it has also become the subject of more detailed research in recent decades with the intellectual roots of critical thinking going back even further than that. They run back at least as far as the etymological interpretation of the word 'critical', which can be traced all the way to Ancient Greece. Etymology is wondrous science in at least two aspects; firstly, it provides a basic clarification of the meaning of words and thus represents a starting point for further research and secondly, because words are always closely related to the mental activity of the period in which we first encounter it and this is precisely how etymology helps us establish a schedule for a particular phenomenon. In Ancient Greek, the word kritikos refers to the ability to judge while the word krinein meant to sift, distinguish or decide. Barry K. Beyer wrote that critical thinking originated from the Greek word kriterion, which can be defined as the criterion for judgment. [2] Thus, from the very beginning of considerations on critical thinking, we are confronted with the concepts that represent the main objectives of education, which we will discuss further on in the continuation of this paper. These concepts include the ability to judge and discriminate, reasonableness, selectivity, and many more. If we take into account the fact that the written word is already a reflection of certain prior knowledge that was not written down, but existed nevertheless, or that such records were lost, it is possible that the history of critical thinking goes back much farther.

The American philosopher, psychologist and pedagogue, John Dewey is considered by many to be the father of the modern theory of critical thinking having written about the form of critical thinking within the framework of reforms to teacher's motivational work with students in 1909. In his work, however, he did not use the term 'critical' thinking, but rather 'reflective' thinking. Concerning his definition of reflective thinking, he wrote that it is the "active, persistent, and careful consideration of any belief or supposed form of knowledge in the light of the grounds that support it" [3 p3] and that we should "learn to think, not only to memorize". [4] Dewey's theories were further developed by Edward B. Glaser, who published a book entitled An Experiment in the Development of Critical in 1941 where he defined critical thinking as one of the main competences of modern education. His view of critical thinking includes enquiry and logic-based reasoning as well as the persistent exploration of beliefs and established knowledge [3 p3]. In terms of the definition of critical thinking, Beyer relies on questions such as whether pupils are able to judge the quality of a newspaper article on a certain topic of significance, whether they are able to judge the quality of a poem, novel, story, film, or a particular article that is political or economic in nature. Furthermore, Beyer questions whether students are able to offer clear arguments for their own thinking. Beyer emphasizes that these brief questions do not encompass the entire spectrum of critical thinking's importance, but gives direction to his understanding. [2 p7]

In the case of Richard Paul, we encounter a somewhat different paradigm of critical thinking, which includes all the essential items of the aforementioned authors, but also 
adds the "reflecting on their own thoughts". [3 p4] Thus, a new component is added to critical thinking: the assessment of external events is upgraded by means of judgment and by evaluating one's own mode of thinking. This originates from the perspective that the quality of our lives and everything that we build or create depends upon the quality of our thoughts. Here, Fisher points out that "excellence of thought must be systematically trained". [3 p4] At this point, we encounter a form of critical thinking that does not only focus on the assessment of external events, but also on the internal events of the observer.

The notion of critical thinking as written by R. Paul offers a challenge. It raises the question of why it would limit critical thinking to the assessment of external events and to the actions of other people. Why should we evaluate ourselves in the same way we evaluate our surroundings? Undoubtedly, it is more difficult to see yourself under the light of judgment, but this is not a sufficient argument to not develop critical thinking within the context of self-assessment. Finally, in the case of assessing both others and external events, without involving ourselves, we are subject to double standards. Applying uniform criteria for assessing oneself and others establishes a consistent personality in an individual, which is undoubtedly one of the goals of education.

\section{What is Mindfulness?}

Let's look at some of the most common and widely used definitions and interpretations of mindfulness. As we have already noted with critical thinking, there is no consensus on its definition. Perhaps this area is even more complicated as although the roots of the mindfulness method extend at least 2500 years into the past, mindfulness, in the context of observing experiences at a deeper level for the general public, has become widespread over the last few decades. One of the first to present mindfulness to the wider secular public was Jon Kabat-Zinn, a doctor of molecular biology. In 1979, he gathered together patients with various chronic illnesses who had failed to respond to classical treatment and included them in a program he called Mindfulness-Based Stress Reduction. Dr. Kabat-Zinn [5] identified mindfulness as a careful awareness of the present moment that is free of judgment. He said that it is an awareness of what is in our mind. He further wrote of mindfulness:

"an awareness of every moment. This is nurtured through deliberate attention to things that we generally do not pay attention to. It is a systematic approach to developing new types of control and wisdom in our lives on the basis of our inner ability to calm ourselves, focus our attention, awareness and insight". [6]

A number of other authors have also identified mindfulness in a similar way. Broderick and Metz wrote that it is a consciousness of the present moment and what we do with a certain mental orientation and free of judgment. [7] Brown states that mindfulness can be defined as direct contact with events in the form in which they appear without discriminatory additions. Brown further states that we are rarely able to competently view events and things impartially, but that they are instead defined within an individual's prior conditionality and internally directed thoughts. [8] The result of this kind of thinking includes concepts, judgments, and "labels". [9] Such an acquired picture of reality is "superficial, incomplete and distorted". [10] Impartial observation, from this perspective, is the first step towards understanding reality, but not the last. Focused attention cannot therefore be the ultimate goal, nor is it an end in itself, therefore, it does not entirely comprise the practice of mindfulness.

In the aforementioned definitions, focused attention or observation appear as the central element of mindfulness. Undoubtedly, when we observe something or focus our attention on something, we create the conditions for further steps such as asking questions, analyzing, and understanding. This raises the question of where these steps lead or what they serve.

We can likely acquire knowledge concerning the functioning of the object of observation. Unbiased observation is the fundamental method for any serious scientific work. It leads to understanding the causes and conditions applicable to certain characters as well as mental states. Understanding gives the observer a greater range of management and operation possibilities in relation to the subject of the treatment. A botanist, for example, observes particular plants, a chemist observes chemical processes, a scientist observes cell function, a and a physicist observes phenomena which are within the sphere of his / her profession. They all acquire valuable information, which serves the steps that follow and allows people to handle them. An example of this is when mankind realized that their knowledge of electricity could be used for general progress. If they did not have this knowledge, electricity would either not be of any help to us or could even hurt someone who did not respect or did not know its laws. To sum up, the practice of mindfulness does not stop at observing without judgment, but goes beyond it. Observation serves a broader goal, which is that of recognizing the causes and conditions of certain phenomenon, the perception of this phenomenon in a broader context, and understanding of the consequences that it brings.

To understand the above record, it is helpful to examine the significance of mindfulness as approached by Buddhism. In professional literature, it is often said that the practice of mindfulness has its origin in "Buddhist psychology, but we find similar conceptual parallels in many traditions in the fields of philosophy and psychology, beginning with the philosophy of ancient Greece" [8 212 p]. 
The term mindfulness came into being at the end of the 19th century as the equivalent of the Pali ${ }^{1}$ term sati. [1 $\left.\begin{array}{ll}10 & 3 \mathrm{p}\end{array}\right]$ Tamara Ditrich further notes that Ancient Buddhist discourse originates in the basic assumption that the suffering and dissatisfaction of human existence ( $d u k k h a)$ can be completely overcome with a deep experiential understanding (pañña) of the activity and causative conditionality of all mental and physical phenomena, which make up the human experience of life. [10 16p] We often translate the word pañ $\tilde{\bar{a}}$ as wisdom and Ditrich states that the pañ $\tilde{a}$ can not appear without sati. [10 17p] In other words, mindfulness or vigilant observation of mental and physical phenomena is one of the components (but not the only one) necessary to develop wisdom or understand the functioning of these phenomena. Simply, knowledge cannot exist without vigilant observation, attention or mindfulness. The significance of knowledge to Buddhist philosophy needs to be understood in a wider dimension and thus as an experiential understanding that represents the component that can completely overcome the suffering and dissatisfaction of human existence. [10 16p] Here it is important to emphasize ethical cognition (kusala), which is inextricably linked with the acquisition of knowledge in Buddhist philosophy. It concerns recognizing the quality of certain mental states, in terms of their consequences on the environment and on the observer himself. This contribution is positive in terms of progress and negative in terms of leaving unwanted consequences and conditions behind. Kusala is therefore an ethical component, which comes from the awareness that good or bad actions are not rewarded or punished for moral reasons, but that they have their own consequences based on the principle of causality. A sentence attributed to Buda describes kusala's inner workings thusly: "You will not be punished for your anger; you will be punished by your anger."

\section{Get to Know Yourself}

In the definition of mindfulness, we are united at least in the fact that it involves (self) observation, and therefore inevitably also vigilance and attention. There is no reason to limit this observation to external events and other people. The subject of research can also be our own minds and the mental processes that take place within them. In the process of education, this is an essential component. The problem of the modern school system is that there is too much emphasis on repetition, so pupils most often remember and repeat what they have heard and read. Focusing attention on yourself and your mental processes adds to education an

1 Pāli is an Indo-Aryan language, or a Prakrit language, which is native to the Indian subcontinent. It is the language of early Buddhism, in which the Theravāda canon is known as the Tipitaka. (Encyclopedia Britannica. Pali language [Internet]; 2017 [cited 2017 June 6]. Available from: https://www.britannica.com/topic/Pali-language) essential, but currently overlooked and neglected component - getting to know yourself. Doubting whether it is necessary or even appropriate to include mindfulness in schools is unnecessary. Without knowledge of yourself, it is difficult (if it is even possible) to develop responsibility, which represents a fundamental competence in the process of education. The importance of knowing yourself is neither a new invention nor a brilliant modern idea, but the necessities and values of the latter were already recognized in Ancient Greece. Giovanni Reale writes that we can summarize all of Socrates' doctrines in two prepositions: "knowing ourselves" and "caring for oneself". [11] Being acquainted with "oneself" does not mean only knowing your name or your body, but observing yourself from within and getting to know your own interior. This cannot be without attention or mindfulness and without critical reflection. However, questions arise as to how and with what approaches we achieve our goal. Professional literature on such methods offers a wide range of possibilities, but, for the purposes of this paper, we only focused on one of these methods - asking questions. The reason for this is that asking questions connects both the method of mindfulness and critical thinking. Here, we can speak of the point of contact between the two practices. At the same time, it is also this method that revitalizes and re-actualizes the work of the Greek philosopher Socrates.

\section{Socrates and Posing Questions}

Siegel Harvey writes in his article, Cultivating Reason, that the vast majority of traditional Western philosophers, from the time of Socrates to this very day, have been keen to cultivate reason and insert it into the foundations of education. [12] Socrates can undoubtedly be counted as among the first to develop a method of critical thinking. In order to achieve this goal, Socrates made methodical questioning the centre of his work. In this, he argued that the individual should not take the indiscriminate opinions and positions of those who are in authority and who are generally convinced that they are being taught. Instead, he defended the importance of posing in depth questions that explore and upset even established positions. "His most marvellous trait was that he would approach Athenians of any class, age, or profession and pose questions without beating around the bush, without worrying about whether they would see him as eccentric or a trouble-maker, would explain precisely why he believed in certain items of common sense and his take the purpose of life". [13]

Boris Vezjak writes that Socrates has left us with very particular situation where being a teacher is not down to transferring knowledge to his students and listeners, but instead wanting them to find it within. Here, the form of Socrates' search was both important and decisive. For example, Vezjak believed that results came from the exchange of words. Vezjak continued that Socrates insisted 
on dialectics, that is, the conversational skills that he perceived to be the sort of skill through which we strive for ultimate and meaningful knowledge. [14] The parallels to modern perceptions of critical thinking are obvious. Teachers can encourage students to develop critical thinking only by ensuring that "the answer is not known in advance and, if it is not, pupils should be invited to collectively research the problem. Therefore, they must create an atmosphere in which students suggest solutions and then explore them. [15] Although the Socratic method aims to engage both teacher and students in an open-ended dialogue that examines their individual beliefs and assumptions, the method has some potential difficulties. If the teacher is not experienced with the Socratic method, it might be difficult for her/him to fit the method into a higly structured curriculum. It might be difficult for the teacher to prepare good questions, and arrange them logically, or to handle the diversity of responses that might be given to any question. The method may fail also if students are not willing to participate or are not motivated to go through or to internalize the process.

The question-posing technique has a clear goal. Instead of providing answers and solutions with this technique, we switch off automatic thinking which Halpern defines as the retrieval of learned information or as an action that contains very little conscious evaluation. [16] All other mental skills that constitute critical thinking should be put towards the analysis of arguments, the judgment of the credibility of sources of information, the implementation of deductive and inductive conclusions along with their judgment, problem solving and decision-making, consideration of one's own thinking and, finally, self-regulation. All of these skills originate in a vital first step, that is, asking a question about a particular topic.

\section{Where do Socrates, Critical Thinking and Mindfulness Meet?}

(Self) questioning is one of the common points between Socrates, critical thinking, and mindfulness. It is not through reflection that we evoke answers, but through questions. Had individuals not asked questions pertaining to various issues throughout history, whether in the field of biology, medicine, physics, philosophy, and so on, the field of science in particular would not have developed. Questions are the first step to stimulating thinking, so they should not be underestimated in the process of building critical thinking. Additionally, there is no reason for these questions to be limited to events that are external in nature, but they can be directed with the same measure of research spirit we have for ourselves, as was stated in the previous chapter. Moreover, the quality of the question is an excellent indicator of the quality of the individual's thinking, as well as the level of knowledge already reached. Teachers should therefore welcome any and every attempt by students to ask questions as well as, of course, cultivate this same quality in them. Above all, the questioning technique can also be used by the teacher to encourage the student to rethink a particular subject.

Questions are also an excellent method for self-regulation when it comes to one's own train of thought. Here are some examples of questions that are generally useful. What results can I expect to see from this course of thought? Will it lead me to my goals? Why am I thinking this way? What are the consequences of my words and actions on my surroundings? Do I build relationships that I want with them or am I distancing myself from them? Of course, it is possible to go back in one's own mind after a certain event has already taken place. School life offers many examples of this, however, tracing one's train of thought is not solely related to school. Let's say that a student received a bad grade on a written examination. In order to avoid further poor grades or at least to improve the situation, it would be reasonable to analyze the causes. Often, the causes are at least partially at home in the individual's mind. If we can manage this mental stream and replace it with a different mode of thinking, it is possible to significantly improve a situation in the future.

As it was already mentioned in chapter three, the value of questions in terms of gaining knowledge was already well known to Socrates. The philosopher did not give away any answers, but asked questions of the co-speaker to trigger reflection. Today, we are faced with a flood of information that people often accept uncritically, thus, education in the spirit of Socratic questioning offers an extremely effective technique for developing critical thinking. Critical thinking cannot circumvent questions, these, of course, are the attributes of a mindful person who is vigilantly aware of the events taking place around him / her.

Socrates overturned the traditional scale of values that had, up until then, been recognized by all of Greece and remained relatively untouched by sophists. The main traditional values were related primarily to the body, for example, life, health, physical power, and beauty or represented external goods or goods associated with the exterior of man such as wealth, power, fame and the like. [11 258p]. Socrates pushes such external values into the background and replaces them with internal values, among which the greatest are the values of knowledge and cognition. The reflections of the Greek philosopher most certainly apply to the world we live in today. Last but not least, the purpose of critical thinking is also to upset the values that often dominate modern society, which leads us to search for speedy solutions, to shift responsibility to others, and so on. With vigilant observation (mindfulness) and critical reflection, we can ask ourselves whether our actions have led us to progress, whether they are useful both to the individual and society as a whole as well as, on the basis of our own findings, whether we are behaving properly. 
Mindfulness and critical reflection lead to knowledge. Here we are not merely addressing formal knowledge, but also about those types of behaviour where the causes and conditions for a particular phenomenon are understood along with the consequences. Knowledge in this context is presented as a form of exit from a variety of crises caused by ignorance. A similar understanding of knowledge is again encountered in Socrates, where the highest virtue is "knowledge" or "cognition" and the opposite of "virtue" is the impoverishment of science and cognition, that is, "ignorance." Socrates goes even further to combine virtues and knowledge in the sense that virtues originate in knowledge and vice versa, thus, that ignorance is the source of all human wrongdoing. The so-called 'wrongdoings' from the perspective of Socrates are not conceptualized from a moral point of view, but, as in Buddhism, they are "responding incorrectly to experiences based on faulty cognition and ignorance" [10 16p], which leads to dissatisfaction and suffering.

\section{Case Study}

Let's look at a practical example, which unites the basic principles of mindfulness and critical thinking. Years ago, I had a student in my class who struggled with Spanish (the subject I teach) from the very beginning. He learned little, usually only accumulating enough knowledge to pass, but as the months and years went by, the situation became more complicated. The amount of materials was consistently increasing and this student's knowledge was so poor that, eventually, he could no longer follow our lessons. This usually brings with it other consequences, such as absenteeism, avoiding assessments, and what we like to call taking shortcuts. In his third year, it became clear that there was a retake exam on the horizon. I informed the student of this. Later on, I learned from other students that he was blaming me for necessity of a retake exam and saying that I was too demanding of a professor. The next school hour I set out to ask a student a few questions. I decided to talk to him in front of the whole class, so I asked the student, "Will considering me as the cause of your retake exam help you succeed? Your final goal is probably to acquire knowledge and receive the positive grade that goes with it, right? Has judging me guaranteed your success? Have your thoughts lead you to actions that will help you pass the year? If this mode of thought will ensure your success, I don't mind, use it. If it's useful, go ahead with it, if not, try to find a better solution." The matter seemed simple and logical, one of those we often like to mention because we all know the answer. But here's the catch: one of the most difficult things to do is to stop thinking the way we have for many years, travelling down the same tracks that we might have taken on from others without thinking about whether or not it makes sense. Automatic thinking can be compared to a huge snowball that started out the size of a fist, but with the constant repetition of our responses to similar situations, it started rolling downhill growing all the way. The teacher's role in such a case is to form an obstacle to this kind of thinking with a question and to break the steady path of this avalanche of thought.

And how did it end for our student facing a retake exam? After three weeks, the student asked for another chance at the oral and written test. This request was completely out of character, so as I became aware of the new developments in the student and I accepted the request. In both cases, the student showed sufficient knowledge for a passing grade. The next school year, he completed the year with a $\mathrm{C}$ (good). When analyzing the events that led him to make such a significant shift in his work habits, the following should be considered:

- The student's teacher offered encouragement in the form of introspection by asking him some questions that caused him to reflect and answer them on his own.

- The student responded to the questions and directed his attention to his mode of thought, which has become the object of his observation.

- In doing so, there is no judgment in the sense that his way of thinking is good or bad, appropriate or inappropriate from a moral point of view or, what is more, that he is good or bad because of the way he thinks. The teacher's attitude is also helpful in terms of asking questions without passing judgment.

- The student examined his mode of thought in a wider context, began to understand the causes and conditions for the emergence of the particular phenomenon, and, at the same time, formulated his own conclusions.

\section{Conclusions}

Regardless of the fact that interest in mindfulness in Slovenian schools is growing, the fact is that there are also many questions, problems and even a resistance to this practice. The reasons are understandable to some extent, as this field has not yet been thoroughly defined. The questions concerning who the authorities or carriers of knowledge in this field are, which written sources constitute competent literature, and which approaches can be considered worthy of trust are all valid. Škodlar, for example, writes that there are three streams of literature on mindfulness. The first issue relates to the preserved and translated written sources of various traditions of Buddhism, the second to modern scientific literature, and the third to popular literature intended for a wider audience. This is why it will probably be necessary to thoroughly discuss the topic of mindfulness in the future. However, as such, certain headwords have been formed. [17] 
According to Siegel, cultivating and nurturing reason is a significant ideal in terms of education. Rationality, however, has become something that biologists would call an "endangered species". [12 306p] We have become a society where schools place (too) great an emphasis on the memorization and repetition of information. Pupils are graded according to the amount of information they remember and are able to repeat. It is unlikely for us to completely avoid this and that is not the purpose. However, a great deal could be achieved if the relationship and emphasis were slightly altered. Introducing practices of mindfulness into the educational process represents the shift in focus from answers to questions and from solutions to searching and verification. The goal of mindfulness is certainly more far-reaching than simply coping with stress and attaining a state of relaxation. Additionally, the purpose of practicing mindfulness is not to look for pleasant feelings and to push away the unpleasant. Mindfulness is the basis for in-depth observation, which continues into critical reflection on the object of observation as well as understanding the causes and conditions necessary for a particular phenomenon, and, last but not least, in placing this phenomenon into a wider context. It is a process based on its own experiential undertakings as well as on the practice of examining attitudes and beliefs.

Teachers play an important role in the development of mindfulness and critical thinking. It is likely that anyone who works with young people has already encountered a question or dilemma about how to awaken in students the desire to think critically and guide students to engage in critical thinking. Without a doubt, we have a number of options and methods available, and we know that everyone will interject to offer the one (s)he thinks most appropriate. However, the most essential point should not be overlooked; this is the teacher's own desire to continuously acquire knowledge. As far as this desire goes, teachers should not relax or be satisfied with what (s)he already knows, but instead should stand as an prime example of a tireless seeker aware that education does not end with a diploma, master's degree or doctorate. If we want young people to be in love with knowledge, then this love of knowledge must first be shown by teachers. With the advent of mindfulness practices, new opportunities for research are opening up to us. Unlike the already accepted facts, research is an incomplete process, which, at first glance, is less pleasant and comfortable. It requires vigilance, as well as some of the courage Socrates had when he recognized his own ignorance. It is precisely at this point that the essence of mindfulness is hidden. Realizing that we do not know something is already the first step to something new. And what more can teachers offer their pupils, if not to be the proof that life is fluid, not only in the physical but also in the mental world.

\section{REFERENCES}

[1] Rupnik Vec, Tanja. Kako spodbujati razvoj kritičnega mišljenja pri pouku s pomočjo nekaterih orodij IKT [Internet]. Ljubljana: ZRSS; 2010 [cited 2017 June 5]. 2 p. Available from:

http://www.zrss.si/projektiess/skladisce/pkp/podprojekt3/\% C4\%8Clanki/Kriti\%C4\%8Dno\%20mi\%C5\%Alljenje/kriti \%C4\%8Dno\%20mi\%C5\%A1ljenje\%20in\%20ikt.doc

[2] Beyer, K. Barry. Critical thinking [Internet]. Bloominghton: Phi Delta Kappa Educational Foundation; 1995 [cited 2017 June 10]. 9 p. Available from:

http://teacherlink.ed.usu.edu/yetcres/catalogs/reavis/385.pdf

[3] Fisher, Alec. Critical Thinking. Cambridge: Cambridge University Press; 2001. 3 p.

[4] Ćurko, Bruno in Strahovnik, Vojko. Etika za najmlajše 3-5 let [Internet]. Učilnica; 2016 [cited 2017 May 15]. Available from:

http://ucilnica.zofijini.net/2016/11/06/etika-za-najmlajse-35-let/

[5] Kabat-Zinn, Jon. Defining Mindfulness [Internet] Foundation for Mindful Society; 2016 [cited 2017 May 5]. Available from:

https://www.mindful.org/jon-kabat-zinn-defining-mindfuln ess/

[6] Arzenšek, Ana. Čuječnost kot psihološka intervencija v psihološkem svetovanju. In: Zalta, A, Ditrich, T. (ed.). Ćuječnost: tradicija in sodobni pristopi [Internet]. Koper: Univerza na Primorskem; 2015 [cited 2017 May 10]; 20 (77/78): 75-94. Available from:

file://C:/Users/Eva/Downloads/Poligrafi\%2077-78 CUJE CNOST_web2.jpg.pdf

[7] Broderick, Patricia and Metz, Stacie. Learning to BREATHE: A pilot trial of a mindfulness curriculum for adolescents. Advances in School Mental Health Promotion [Internet]. West Chester: University of PA, USA; 2009 [cited 2017 May 10]; 2(1) 35-45. Available from: http://citeseerx.ist.psu.edu/viewdoc/download?doi=10.1.1.4 $53.4080 \&$ rep $=$ rep $1 \&$ type $=$ pdf

[8] Brown, Kirk-Warren. Mindfulness: Theoretical Foundations and Evidence for its Salutary Effects. Psychological Inquiry [Internet]. London: Psychology Press; 2007 [cited 2017 April 26] 18(4), 211-237 p. Available from: http://www.psy.cmu.edu/ creswell/papers/Brown,\%20Rya n, $\% 20 \& \% 20$ Creswell $\% 20(2007), \% 20$ Mindfulness $\% 20$ The ory $\% 20$ and $\% 20$ Effects, $\% 20$ Psychological $\% 20$ Inquiry.pdf

[9] Bargh, J. A., \& Chartrand, T. L. The unbearable automaticity of being. American Psychologist [Internet]. New York: New York University; 1999 [cited 2017 May 16]; 54, 462 p. Available from:

http://psych415.class.uic.edu/Readings/Bargh,\%20Auotmat icity,\%20AmPsy,\%201999.pdf

[10] Ditrich, Tamara. Predstavitve sati v zgodnjem budizmu. In: Zalta, A, Ditrich, T. (ed.), Čuječnost: tradicija in sodobni pristopi [Internet]. Koper: Univerza na Primorskem; 2015 [cited 2017 June 3]; 20(77/78), 13-34 p. Available from: http://www.zrs-kp.si/revije/single/poligrafi-77-78-cujecnost -tradicija-in-sodobni-pri-2011

[11] Reale, Giovanni. Zgodovina antične filozofije (zv.1). Ljubljana: Studia humanitattis; 2002. 252 p. 
[12] Siegel, Harvey. Cultivating Reason. In: A Companion to the Philosophy of Education; (ed. Randall Curren). Blackwell Publishing; 2003. 305 p.

[13] Botton, Alain. Utehe filozofije. Ljubljana: Vale-Novak; 2004. 20-21 p.

[14] Vezjak, Boris. Sokratov pojmovnik za mlade. Maribor: Aristej; $2011.47 \mathrm{p}$.

[15] Adam, Andrej. Kritično mišljenje in njegovo utemeljevanje. Zofijini ljubimci. Društvo za razvoj humanistike [Internet]. 2010 March 27 [cited 2017 June 17]. Available from: http://zofijini.net/modrost_kriticno/

[16] Halpern F., Diane. Thought \& Knowledge. An Introduction to Critical Thinking. Mahwah, NJ: Lawrence Erlbaum Associates; 2003.7 p.

[17] Škodlar, B., Srakar, D. (2015). Čuječnost v psihoterapiji. In: Zalta, A, Ditrich, T. (ed.), Cuječnost: tradicija in sodobni pristopi [Internet]. Koper: Univerza na Primorskem; 2015 [cited 2017 June 6]; 20(77/78), 59 -74 p. Available from: http://www.zrs-kp.si/revije/single/poligrafi-77-78-cujecnost -tradicija-in-sodobni-pri-2011. 